\title{
現場だより
}

\section{東京大学生産技術研究所 機能エレクトロニクス研究センター}

正会員 高 木 幹 雄 $^{\dagger}$

東京大学生産技術研究所は, 昭和 24 年に「生産技術 に関する技術的問題の科学的総合研究ならびにその実 用化」を目的として発足した東京大学の附置研究所で, 大学の附置研究所としては最大の規模を有し, 43 の 研究部門に 3 センターを併わせて約 430 名の教職員, 約 200 名の大学院学生, 約 120 名の受託研究員, 研究 生の総勢約 750 名が, 都心の六本木キャンパスで頭脳 集約的な高度な研究に日夜励んでいる。

他の附置研究所が地震, 海洋, 物性など特定の分野 の研究を行うために設立されているのに対し, 本研究 所は工学全般を扱っている点が異なっている。また, 研究体制の面でも独特で, 講座制, 部門制をとらず に, 研究室制, 専門分野制をとり, 各教授, 助教授, 講師が独立の研究室を運営し, 研究者の自由な発想の 下に自主的に研究テーマを選択して進めると共に, 各 研究者が自由にグループを作って研究を進めることも できる.さらに, 将来性が期待される萌芽的研究を積 極的にとり上げ, 多数の研究者が総合的に協力して研 究開発を進める態勢があり, 最近の新しい研究分野が 多くの専門領域を包含した学際的なものが多いことに 整合している.古くはペンシルロケットに始まり, 宇 宙工学研究所に移管された観測ロケットから, 試験溶 鉱炉, 省資源技術, 耐震工学, 画像工学などがその好 例である. なお, 重点的研究課題に関しては, 研究セ ンターを設立し, 集中的に研究する体制をとってお り, 現在までに計測技術開発センター, 多次元画像情 報処理センター, 複合材料センター, 機能エレクトロ ニクス研究センター, 先端素材開発センターが設立さ れ, 活発に研究を行ってきた.

「機能エレクトロニクス研究センター」は, 昭和 59 年 4 月 11 日付で発足した. 本研究センターは, 昭和 52 年に設置された「多次元画像情報処理センター」の 7 年の時限満了に引き続いて設立されたもので, 「多 次元画像情報処理センター」で精力的に研究され大き な成果を挙げた画像情報処理をさらに発展させた新し

$\dagger$ 東京大学 生産技術研究所
い情報処理（機能情報処理）と，新しい電子デバイス （機能デバイス）との有機的結合を目指しており，

機能情報処理 : 高木幹雄教授, 喜連川優助教授

機能デバイス: 生駒俊明教授, 坂内正夫助教授 の 2 部門で構成されている.

「多次元画像情報処理センター」では, 初期的研究 段階にあった画像処理に逸早く着目し，「多次元画像 情報処理」という包括的な立場で総合的な研究を行い, 今日の画像処理の研究が隆盛となるのに寄与した. 「多次元画像情報処理」では, 画像を 2 次元のパターン の他に, 濃淡, 色彩, 波長, 時間を含む多次元の情報 として捉え, これらの計測, 解析, 認識を目的とした 処理手法の開発を行うと共に, 医用画像, 衛星画像, 産業用画像等に応用して, 学術, 産業に有効な情報を 提供して来た。

情報化社会の高度化に伴って, 情報処理の対象は， 数值・文字から, 音声, 図形, さらに画像情報の処理 へと進み, 次の対象は「機能情報」と考えられる。こ れは, 画像情報より一層高度な情報を対象とした処理 を要求している。一方, 情報処理の急激な発展を支え て来たのは, ハードウェアの面ではVLSI を可能とし たデバイスの長足な進歩と, ソフトウェアの面では情 報処理の各種アルゴリズムの開発に負う所が大きく, デバイスと情報処理という広い意味のエレクトロニク スの進歩によるものである. 本研究センターは, ハー ドウェアの面では新しい機能を有するデバイスの開発 のための基礎的な研究を行うと共に, ソフトウェアの 面では情報の中から機能を引出すような新しい情報処 理の手法を確立し, その両者が緊密な連絡の下に総合 的に研究を進めようとしている.

「機能情報処理」では, 多次元画像, 地図情報など に含まれる膨大な情報を効率的にデータベース化し， 知識工学的手法により自動的に合目的化して処理・利 用する技術とその応用を研究する。

（1）機能に影響する極めて多種, 異質, 膨大な情報合目 的的に抽出, 収集し, 理解して機能情報知的データベー 

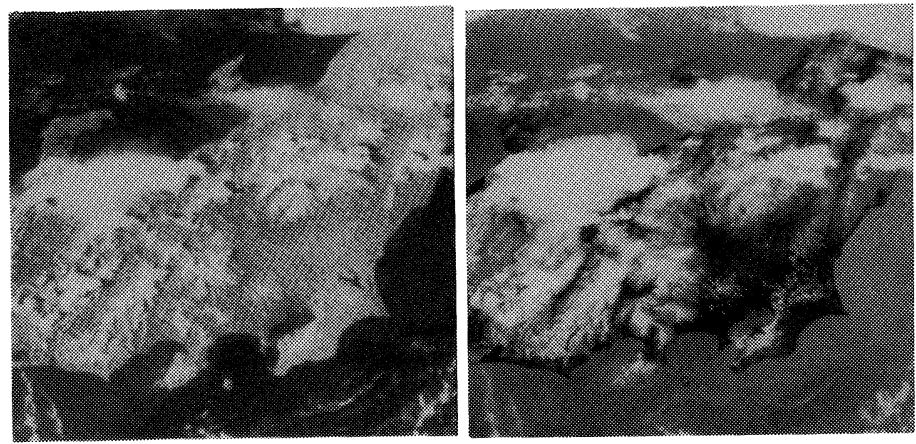

写真 1 気象衛星 (NOAA) 画像 (左: 可視, 右: 赤外). 極軌道型 の気象衛星 (NOAA) は, 我が国周辺の環境を調査するの に適している. 気象衛星からのデー夕を毎日受信し, 処理 を行い, 気象学, 海洋学などに有効な情報を抽出すること を試みている
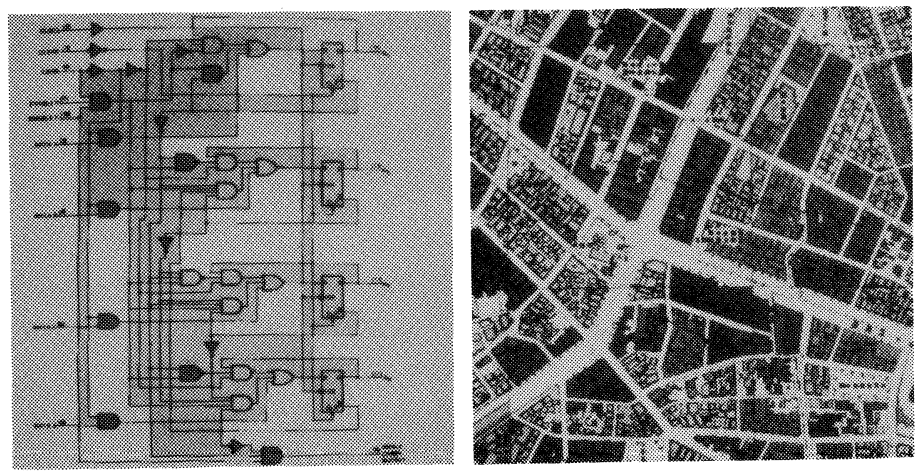

写真 2 知識ベースを用いた多目的図面処理システム NOGISA$\mathrm{KA}$ の出力例. 地図, 論理設計図, 各種パターン図等異質 な図面群から同一の処理方式で所望の情報を合目的的に認 識・抽出できる、機能情報処理の一つの実現例である

スを構成する手法

（2）機能情報知的データベースから各種 の対象に対して人間に必要な情報や機能 の設計・評価を可能とする合目的的（知 的）コンピュー夕利用技術

(3) 知的機能・学習能力を持ったコンピ ュータと人間との知的対話技法に基づく 高度なコンピュー夕利用技術

（4）「機能デバイス」で研究される新しい 機能デバイスを利用するための高速機能 を有するコンピュータアーキテクチャの 研究

「機能デバイス」においては, 機能デ バイスの概念に基づく全く新しい構造の 電子デバイスの研究とその設計手法の研 究開発を行う。すなわち, 半導体・絶縁 物・金属等の電子材料を, 2 次元的に複 雑に組合せた構成をとることによって生 じる, 新しい電子材料としての機能の発 現と，それを応用した新しいデバイスの 研究を行う.

特に, 次の点が研究の対象となる.

（1）数一数 $10 \mathrm{~nm}$ の寸法の電子材料の組 合せによる新物性現象とそのデバイスへ の応用の研究

（2）原子層オーダでの界面の制御と評価 技術の開発

（3）非平衡電子群の性質に基づく極短時 間の現象の解明とそのデバイスへの応用 の研究

（4）「機能情報処理」分野で研究される新 しいコンピュータ利用技術の活用と電子 材料の諸機能の機能情報知識データベー

スとして組織化し，新しい機能デバイスやポストVLSI 用集積回路の設計と実現



写真 3 超高速 LSI 基板として開発中の半絶縁性 $\mathrm{GaAs}$ 単結晶基板の, 電気的・光学的不均一 性を評価するための光電流分布測定装置. YAG または $\mathrm{He}-\mathrm{Ne}$ レーザービームを絞り， 結晶基板内を走査して, 抵抗率や結晶欠陥 (深い準位)の分布を測定できる。機能デバイ ス実現に必要な新物性現象解明の一つの手段 である
以上, 本研究センタで行う研究の方向について述べ たが, 現在行っている具体的テーマとしては,

(1) 衛星データの取得と処理

（2）画像からの機能情報の抽出

(3) 多次元デー夕構造とその応用

（4）機能分散型計算機アーキテクチャ

（5）へテロ電子材料の成長・評価とデバイス応用

（6）集束イオンビーム使用の機能デバイスの試作と応用

（7）機能デバイスの解析と高次 CAD

（8）化合物混晶中の欠陥物性

などがある. 写真 $1,2,3$ に現在行っている研究の例 を示す．先に述べたような方向で研究を指向している ものの，末だ発足後間もないので，充分な成果を挙げ ているとは言えないが，一層の努力をする所存であ る. 皆様のご激励, ご鞭撻をお願いしたい. なお, 昭 和 59 年度の研究成果論文集を取りまとめているので, ご興味のある方は筆者までご連絡頂きたい。 